\title{
EVALUASI KONDISI KERJA PADA UMKM PERCETAKAN MENGGUNAKAN WORK IMPROVEMENT IN SMALL ENTERPRISES (WISE)
}

\author{
Novi Devita Sari, Irwan Iftadi, I Wayan Suletra \\ Program Studi Teknik Industri, Fakultas Teknik, Universitas Sebelas Maret \\ Email: devitanovi44@gmail.com; irwaniftadi@staff.uns.ac.id; suletra@staff.uns.ac.id \\ Artikel masuk : 05-01-2021 \\ Artikel direvisi : 14-04-2021 \\ Artikel diterima : 26-04-2021 \\ *Penulis Korespondensi
}

\begin{abstract}
Abstrak -- Percetakan XYZ merupakan salah satu UMKM yang memproduksi tulisan atau gambar untuk kepentingan periklanan, salah satunya adalah spanduk. Percetakan tersebut mempunyai beberapa permasalahan terkait kondisi kerja serta belum adanya kesadaran dalam menerapkan Keselamatan dan Kesehatan Kerja (K3) di tempat kerja. Tujuan penelitian ini adalah melakukan evaluasi kondisi kerja serta merancang usulan perbaikan untuk kondisi kerja yang lebih produktif dan sesuai dengan pedoman K3 di percetakan XYZ. Program Work Improvement in Small Enterprises (WISE) dengan pendekatan Participatory Action Oriented Training (PAOT) dilakukan dengan melibatkan partisipasi aktif dari pemilik usaha serta pekerja dalam melakukan evaluasi kondisi kerja, pembuatan rencana aksi perbaikan serta implementasi usulan perbaikan. Hasil evaluasi kondisi kerja menggunakan daftar periksa WISE, menunjukkan terdapat 13 elemen periksa yang membutuhkan suatu usulan perbaikan. Melalui metode focus group discussion (FGD) didapatkan hasil bahwa perbaikan yang akan diprioritaskan untuk diimplementasikan dalam waktu dekat adalah 4 elemen periksa karena mempertimbangkan faktor biaya, waktu, dan sumber daya manusia di lapangan. Perbaikan pertama adalah pembuatan jadwal rutin untuk pemeriksaan mesin serta jaringan kabel listrik dengan penerapan 5R. Perbaikan kedua adalah pembuatan tanda bahaya pencegahan kebakaran. Perbaikan ketiga adalah pembuatan tanda himbauan pemakaian pelindung diri masker dan sarung tangan. Perbaikan keempat adalah pembuatan label untuk menuliskan identitas produk sehingga memudahkan pekerja mengenali produk yang berada di area penyimpanan. Evaluasi serta usulan perbaikan kondisi kerja tersebut dapat membantu UMKM dalam meningkatkan kesadaran akan K3 dan mengurangi risiko terjadinya kecelakaan kerja.
\end{abstract}

Kata kunci: K3; Kondisi Kerja; UMKM; WISE

\begin{abstract}
X Y Z$ Printing is one of the MSMEs that produces text or images for advertising purposes, one of which is a banner. This printing press has several problems related to working conditions, and there is no awareness of implementing Occupational Safety and Health (K3) in the workplace. The purpose of this study was to evaluate working conditions and design improvement proposals for more productive working conditions and in accordance with the K3 guidelines in XYZ printing. The Work Improvement in Small Enterprises (WISE) program with the Participatory Action Oriented Training (PAOT) approach involves the active participation of business owners and workers in evaluating working conditions, making corrective action plans, and implementing improvement proposals. The evaluation of working conditions using the WISE checklist shows that 13 check elements require a proposal for improvement. Through the focus group discussion (FGD) method, the results show that the improvements that will be prioritized for implementation are 4 check elements because they consider the factors of cost, time, and human resources in the field. The first improvement is creating a routine schedule for checking machines and electrical wiring with the implementation of the $5 R$. The second fix is the creation of a fire prevention hazard alert. The third improvement is making a sign calling for the use of personal protective masks and gloves. The fourth improvement is making labels to write product identities to make it easier for workers to recognize products in the storage area. Evaluations and suggestions for improving working conditions can help MSMEs increase awareness of $K 3$ and reduce the risk of work accidents.
\end{abstract}

Keywords: OSH; Working Condition; MSMEs; WISE 


\section{PENDAHULUAN}

Percetakan XYZ merupakan salah satu usaha mikro, kecil dan menengah (UMKM) yang memproduksi beberapa jenis produk yaitu spanduk, stiker, cetak A3 dan lain sebagainya. Berdasarkan hasil observasi awal, terdapat beberapa permasalahan pada kondisi kerjanya serta belum adanya penerapan Keselamatan dan Kesehatan Kerja (K3) di tempat kerja. Permasalahan pertama yaitu terdapat alat-alat perkakas tangan serta produk work in process dan produk jadi spanduk yang diletakkan di lantai. Permasalahan kedua yang ditemukan adalah kurang terorganisirnya sampah yaitu limbah hasil produksi. Tempat sampah yang disediakan perusahaan tidak cukup untuk menampung limbah tersebut, karena kapasitasnya lebih kecil daripada volume limbah yang ada. Akibatnya di beberapa sudut ruangan terdapat tumpukan sampah yang mengurangi nilai fungsional area tersebut.

Permasalahan yang ketiga merupakan kondisi yang memperlihatkan belum adanya penerapan $\mathrm{K} 3$ di percetakan $\mathrm{XYZ}$ yaitu rendahnya kesadaran, akan pentingnya keberadaan sarana proteksi kebakaran. Padahal percetakan merupakan suatu industri yang proses produksinya menggunakan mesin-mesin listrik dengan risiko korsleting serta penggunaan bahan baku plastik dan kertas dengan risiko mudah tersulut oleh api. Sekitar 62,8\% kasus kebakaran di Indonesia disebabkan oleh listrik atau adanya hubungan pendek arus listrik (Purwo, 2010).

Selain potensi kebakaran, sumber potensi bahaya kimia juga ditemukan di percetakan $X Y Z$, salah satunya adalah tinta mesin cetak yang mengeluarkan aroma tajam dan menyengat. Menurut International Labour Organization (2013) semua bahan kimia harus dianggap sebagai sumber potensi bahaya sampai dampak bahan kimia tersebut sepenuhnya diketahui. Pekerja percetakan yang menghirup udara tercemar tinta dan bahan kimia lain setiap hari, dapat meningkatkan risiko memburuknya asma hingga 3 kali lipat (Ashari et al., 2013). Namun dalam praktiknya, pekerja kurang sadar akan pentingnya menggunakan Alat Pelindung Diri (APD) seperti masker dan sarung tangan yang tujuannya adalah mengurangi intensitas terpapar tinta sebagai bahan kimia tersebut.

Berdasarkan wawancara kepada 10 pekerja percetakan terkait keluhan atau kecelakaan akibat kerja yang mungkin dialami pekerja selama rentang waktu setahun terakhir, 8 orang diantaranya tersandung ketika berjalan di area produksi akibat peralatan dan produk yang diletakkan di lantai. 3 dari 10 pekerja mengeluhkan gangguan pernapasan hingga kepala pusing dan perut mual akibat paparan bau tinta yang menyengat. Terjadinya hubungan arus pendek atau korsleting juga dikeluhkan oleh 6 orang pekerja percetakan.

Beberapa penelitian terkait penggunaan WISE juga telah dilakukan sebelumnya di beberapa UMKM. Damarasri et al. (2013) menggunakan daftar periksa WISE dan daftar periksa GMP (Good Manufacturing Practice) untuk menghasilkan perbaikan sistem kerja yang sehat dan aman. Hasil dari penelitian ini yaitu terdapat 16 aspek yang menjadi prioritas perbaikan sistem kerja. Suhardi et al. (2019) mengevaluasi kondisi kerja perusahaan roti menggunakan WISE dan menyusun prioritas masalah dengan metode diskusi bersama pihak perusahaan menghasilkan 12 elemen yang membutuhkan adanya tindakan perbaikan, namun hanya 4 elemen yang menjadi prioritas perbaikan. Evaluasi pada industri kerupuk menggunakan daftar periksa CPPB (Cara Produksi Pangan yang Baik) serta WISE menghasilkan 5 priotitas perbaikan dengan penerapan budaya 5S (Suhardi et al., 2018). Rahma \& Hasanudin (2019) melakukan identifikasi bahaya dan penilaian risiko pada industri gamelan menggunakan metode HAZOP dan penilaian penerapan K3 menggunakan WISE. Evaluasi kondisi eksisting industri roti menggunakan daftar periksa GMP, CPPB, dan WISE menghasilkan SOP untuk perbaikan beberapa proses produksi (Suhardi, et al., 2019).

Evaluasi lebih lanjut diperlukan pada kondisi kerja percetakan XYZ menggunakan program Work Improvement in Small Enterprises (WISE) dan pendekatan Participatory Action Oriented Training (PAOT). Penggunaan program WISE menjadi salah satu upaya perbaikan secara berkala dan progresif yang dilakukan oleh pemerintah untuk meningkatkan kesadaran serta motivasi dari pekerja dan pengusaha untuk perbaikan lingkungan kerja yang sesuai dengan standar penerapan K3 sehingga angka kecelakaan kerja di perusahaan skala kecil dan menengah dapat berkurang (Kementerian Ketenagakerjaan Republik Indonesia, 2015).

Program WISE memiliki beberapa kelebihan yaitu praktik mudah serta berbiaya rendah namun memiliki manfaat yang jelas, meningkatkan kemampuan juga kepercayaan diri pemilik usaha sekaligus pekerja dalam mengimplementasikan perbaikan yang efektif serta efisien, dan menekankan keterlibatan pengusaha serta pekerja dalam menghasilkan ide, memprioritaskan perbaikan, dan membuat perubahan aktual di tempat kerja (International Labour Organization, 2004).

Penelitian ini menggunakan pendekatan yang bersifat Participatory Action Oriented Training (PAOT), sehingga pemilik usaha dan 
pekerja percetakan akan dilibatkan pada setiap tahapan penelitian, yaitu tahapan evaluasi kondisi kerja menggunakan daftar periksa WISE, tahapan penyusunan detail rencana perbaikan, tahapan pembuatan keputusan perbaikan mana yang akan diimplementasikan dalam waktu dekat dan waktu mendatang, serta tahapan implementasi perbaikan dalam waktu dekat. Alasan utama mengadopsi pendekatan partisipatif di UMKM adalah meningkatkan partisipasi aktif oleh pemilik usaha dan pekerja dalam mengambil tindakan perbaikan dengan memanfaatkan sumber daya yang ada (Kazutaka, 2012).

Kebutuhan dan kegiatan percetakan akan terus meningkat seiring dengan meluasnya penggunaan teknologi yang maju sehingga diperlukan adanya pengendalian yang tepat untuk mencegah terjadinya kecelakaan kerja pada industri percetakan (Darwis et al., 2020). Tujuan penelitian ini adalah melakukan evaluasi kondisi kerja serta merancang usulan perbaikan untuk kondisi kerja yang lebih produktif dan sesuai dengan pedoman $\mathrm{K} 3$, sehingga dapat membantu UMKM meningkatkan kesadaran akan $\mathrm{K} 3$ dan mengurangi risiko terjadinya kecelakaan kerja.

\section{METODE PENELITIAN}

Tahapan observasi dilakukan dengan metode non-partisipan yaitu peneliti hanya mengamati dari luar saja, tak terlibat secara langsung dalam proses produksi. Selain pengamatan langsung, data dan informasi dihimpun melalui wawancara kepada stakeholder percetakan yaitu pemilik usaha dan pekerja. Wawancara terkait keluhan dan kecelakaan akibat kerja yang mungkin dialami pekerja dalam rentang waktu satu tahun terakhir (Maret 2019 - Maret 2020) dilakukan pada semua pekerja percetakan yang berjumlah 10 orang. Pengamatan dan wawancara dilakukan untuk mengetahui alur proses produksi, bagaimana kondisi kerja serta penerapan keselamatan dan kesehatan kerja pada proses produksi percetakan XYZ.

Tahapan pelaksanaan program WISE merupakan tahap mengevaluasi lingkungan kerja percetakan $X Y Z$ untuk memperoleh data terkait permasalahan kondisi kerja yang ada. Alat yang digunakan adalah daftar periksa Work Improvement in Small Enterprises (WISE), yang merupakan salah satu program Kementrian Ketenagakerjaan yang bekerja sama dengan International Labour Office (ILO) Jakarta.

Sembilan aspek yang menjadi fokus pada program WISE adalah:

1. Aspek penyimpanan dan penanganan material terdiri dari 10 elemen periksa

2. Aspek desain tempat kerja terdiri dari 10 elemen periksa

3. Aspek keamanan mesin produktif terdiri dari 4 elemen periksa

4. Aspek lingkungan fisik terdiri dari 9 elemen periksa

5. Aspek proteksi bahaya listrik terdiri dari 9 elemen periksa

6. Aspek penanggulangan bahaya kebakaran terdiri dari 9 elemen periksa

7. Aspek fasilitas kesejahteraan terdiri dari 5 elemen periksa

8. Aspek organisasi pekerjaan terdiri dari 2 elemen periksa

9. Aspek kondisi lain yang ditemukan

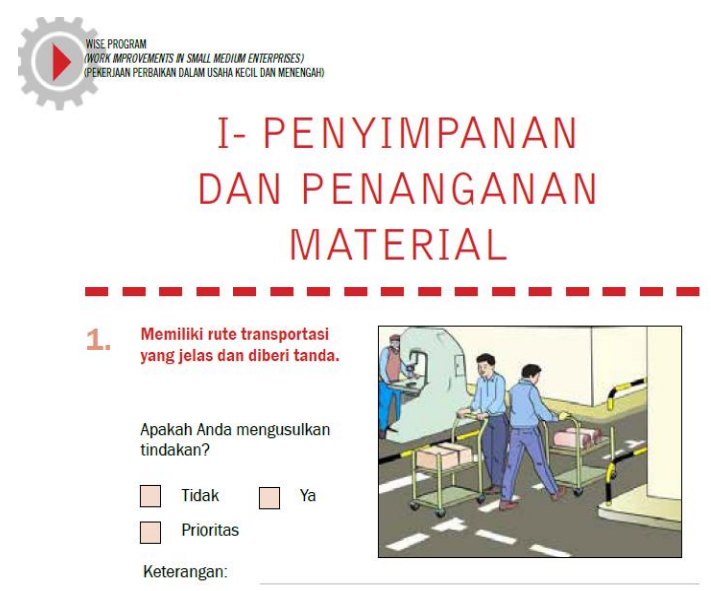

Gambar 1. Tampilan Daftar Periksa WISE

Gambar 1 merupakan tampilan daftar periksa WISE, dimana memuat elemen periksa, dokumentasi praktik yang dianjurkan, serta pilihan "YA" dan "TIDAK" untuk keputusan pemberian usulan perbaikan.

Langkah-langkah pelaksanaan Program WISE menurut International Labour Organization (2004) adalah sebagai berikut:

1. Penilaian Kondisi Kerja dengan Daftar Periksa WISE

Langkah ini dimulai dengan memperkenalkan program serta menyampaikan maksud dan manfaat dari pelaksanaan program WISE. Karena percetakan menerapkan 2 shift kerja (shift A dan shift $B$ ) yang tidak memungkinkan pelaksanaan setiap tahapan WISE dapat melibatkan semua pekerja dalam waktu bersamaan, maka dipilihlah 6 pekerja dari shift A beserta pemilik usaha untuk menjadi partisipan (Tabel 1).

Masing-masing partisipan difasilitasi daftar periksa WISE serta diberi pelatihan cara untuk pengisiannya, yaitu memilih "YA" untuk elemen periksa yang memerlukan perbaikan dan memilih "TIDAK" untuk elemen periksa yang tidak memerlukan perbaikan. Hasil penilain dari masingmasing partisipan akan di buat rekapitulasinya 
Tabel 1. Profil Partisipan Penelitian

\begin{tabular}{|c|c|c|c|c|c|}
\hline No & $\begin{array}{c}\text { Nama } \\
\text { (Inisial) }\end{array}$ & $\begin{array}{c}\text { Jenis } \\
\text { Kelamin }\end{array}$ & $\begin{array}{c}\text { Umur } \\
\text { (tahun) }\end{array}$ & $\begin{array}{l}\text { Pendidikan } \\
\text { Terakhir }\end{array}$ & $\begin{array}{l}\text { Area } \\
\text { Kerja }\end{array}$ \\
\hline 1 & AP & L & 42 & Sarjana & $\begin{array}{l}\text { Pemilik } \\
\text { usaha }\end{array}$ \\
\hline 2 & JRS & $P$ & 22 & SMK & Admin \\
\hline 3 & $\mathrm{MH}$ & L & 25 & SMK & $\begin{array}{l}\text { Desain } \\
\text { Mesin }\end{array}$ \\
\hline 4 & $B L$ & L & 24 & SMK & $\begin{array}{c}\text { cetak \& } \\
\text { cutting }\end{array}$ \\
\hline 5 & SS & L & 27 & SMK & Seaming \\
\hline 6 & AK & L & 22 & SMK & $\begin{array}{c}\text { Keling } \\
\text { ring }\end{array}$ \\
\hline 7 & FP & $\mathrm{L}$ & 20 & SMK & Finishing \\
\hline
\end{tabular}

2. Pembuatan Rencana Aksi

Rekapitulasi hasil penilaian kondisi kerja masing-masing partisipan yang didapatkan dari tahap sebelumnya dapat digunakan sebagai bahan diskusi dalam tahapan ini. Tahap ini dilakukan menggunakan metode FGD yang melibatkan seluruh partisipan untuk menyusun rencana aksi. Rencana aksi berisi daftar permasalahan dan usulan perbaikan yang akan diimplementasikan dalam waktu dekat. Detail rencana aksi ini dibuat dalam analisis $5 \mathrm{~W} 1 \mathrm{H}$.

3. Implementasi Usulan Perbaikan dalam Waktu Dekat

Perbaikan yang akan diimplementasikan dalam waktu dekat merupakan perbaikan yang telah mempertimbangkan faktor biaya, waktu, dan sumber daya manusia.

\section{HASIL DAN PEMBAHASAN}

Produk yang menjadi fokus penelitian ini adalah spanduk, karena menjadi produk yang angka produksinya paling tinggi di setiap bulan. Pembuatan spanduk dilakukan melalui enam tahapan yaitu pertama tahap desain dengan software Corel Draw, desain yang disetujui konsumen kemudian dikirim dari komputer desain ke mesin cetak guna dilakukan tahap cetak dan cutting/ pemotongan. Selanjutnya yaitu tahap seaming/pengepresan sisi-sisi bekas pemotongan. Terakhir adalah tahap pemasangan keling ring dan finishing.

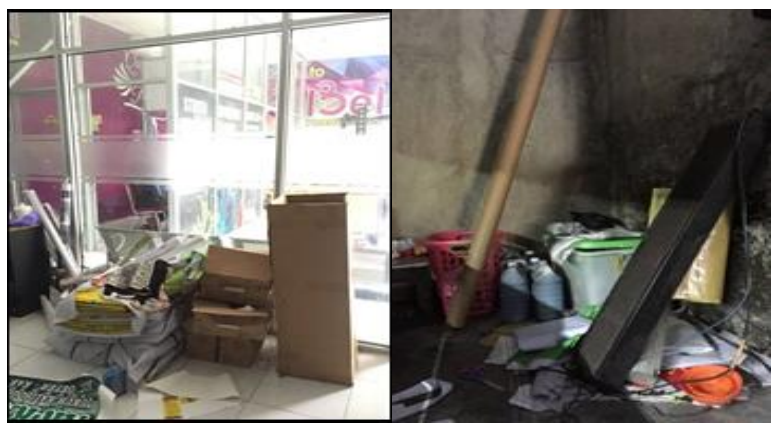

Gambar 2. Kondisi Fisik Percetakan

Kondisi fisik dari aspek penyimpanan dan penanganan material yang ada di percetakan belum mempunyai belum ada sistem pengelolaan tempat/ lingkungan kerja (Management Good Housekeeping) (Gambar 2). Percetakaan tidak ada pengelolaan atau tempat penyimpanan untuk material, alat-alat perkakas tangan serta produk spanduk, tetapi hanya ditempatkan di lantai. Hal tersebut menjadi salah satu penyebab pekerja tersandung produk work in process atau finish good dan tersandung alat kerja yang mana merupakan bentuk dari near miss karena sejauh ini tidak memunculkan kerugian atau luka serius pada manusia.

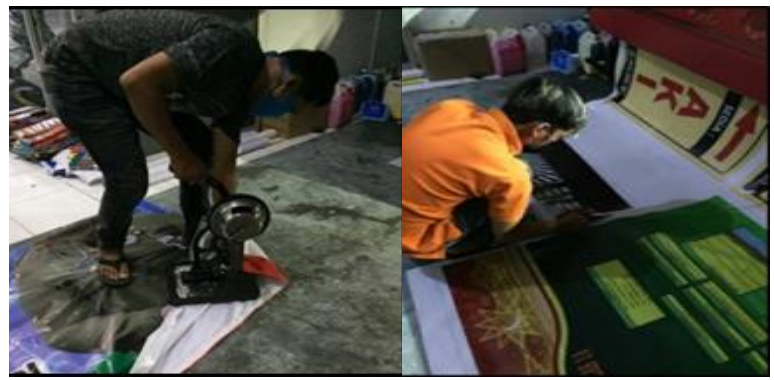

Gambar 3. Gerakan Operator Cutting dan Kelling Ring

Kondisi kerja percetakan masih kurang memperhatikan aspek desain tempat kerja (Gambar 3). Tidak ada penyesuaian ketinggian bekerja sehingga menimbulkan keluhan kesehatan seperti nyeri di punggung dan kaki yang diakibatkan oleh gerakan jongkok dan membungkuk pada operator cutting dan kelling ring dimana aktivitas dilakukan di lantai. Gerakan jongkok dan membungkuk merupakan sikap kerja yang tidak ergonomis sehingga pada akhirnya dapat menimbulkan keluhan-keluhan seperti gangguan pada sistem muskuloskeletal (Manuaba, 1990).

Aspek keamanan mesin produktif pada percetakan perlu diperhatikan karena kurangnya kesadaran pekerja terhadap aspek kebersihan dari mesin yaitu masih adanya tinta-tinta dan debu yang menempel dibiarkan begitu saja, seringkali menyebabkan bahan baku spanduk/ kertas kotor. Selain itu tidak adanya tempat sampah terpisah untuk jenis limbah yang berbeda, serta kurangnya kapasitas tempat sampah untuk menampung limbah produksi, juga menimbulkan permasalahan lain yaitu tumpukan sampah di tempat-tempat yang seharusnya dapat dimanfaatkan untuk aktivitas lain.

Selain permasalahan pada pengelolaan tempat kerja dan limbah, terdapat juga permasalahan pada iklim kerja percetakan yang termasuk dalam aspek lingkungan fisik WISE. Penggunaan atap dari seng menyebabkan suhu di percetakan khususnya di area pencetakan spanduk terbilang cukup tinggi karena berada pada kisaran $29^{\circ}-31^{\circ} \mathrm{C}$, sedangkan standar 
temperatur yang direkomendasikan oleh Kementerian Kesehatan RI untuk ruangan industri yaitu berkisar antara $18^{\circ} \mathrm{C}$ sampai $30^{\circ} \mathrm{C}$. Beberapa faktor yang menyebabkan hal tersebut selain penggunaan atap dari seng adalah sistem ventilasi yang kurang memadai, serta penggunaan mesin-mesin yang prinsip kerjanya melibatkan energi panas.

Minimnya perhatian pada aspek proteksi bahaya listrik beberapa kali juga menyebabkan kecelakaan kerja yaitu pekerja terkena sengatan listrik serta terjadinya hubungan arus pendek pada jaringan listrik mesin-mesin yang digunakan. Kecelakaan listrik tersebut termasuk dalam incident/minor accident karena menimbulkan cedera ringan serta kerugian untuk percetakan karena berhentinya produksi selama proses perbaikan mesin. Kondisi percetakan juga belum memenuhi aspek penanggulangan bahaya kebakaran. Padahal penggunaan mesin-mesin listrik terdapat risiko korsleting serta penggunaan bahan baku plastik dan kertas dengan risiko mudah tersulut oleh api yang dapat menimbulkan kebakaran dengan kerugian lebih besar.

Percetakan telah menyediakan fasilitas minum, kamar kecil sebagai bentuk aspek fasilitas kesejahteraan untuk pekerja. Namun hal tersebut perlu ditingkatkan dengan fasilitas lain seperti penyediaan pelindung pribadi serta peralatan pertolongan pertama dengan tujuan memberikan perlindungan yang memadai untuk pekerja dari bentuk keluhan maupun kecelakaan selama melakukan pekerjaan. Salah satu keluhan kesehatan yang dirasakan pekerja adalah rasa pusing dan mual ketika terpapar bau tinta yang menyengat.

Baik keluhan pada tubuh, near miss maupun incident diatas perlu dievaluasi sumber dan penyebabnya, agar di waktu mendatang tidak berpotensi pada kecelakaan yang menimbulkan kerugian (major accident/serious injuries). Menurut piramida kecelakaan Heinrich maupun piramida kecelakaan Bird, near miss dan incident/minor accident yang terulang dalam ratio yang tinggi berpeluang memunculkan mayor accident dengan kerugian fatal (Hughes \& Ferrett, 2015). Evaluasi lebih lanjut terhadap kondisi percetakan akan dilakukan menggunakan daftar periksa WISE, dimana di dalam daftar periksa tersebut telah memuat contoh gambar kondisi kerja yang baik. Sehingga diharapkan mampu memunculkan ide-ide perbaikan dari partisipan untuk percetakan.

\section{Hasil Penilaian Kondisi Kerja dengan Daftar Periksa WISE}

Penilaian kondisi kerja pada percetakan XYZ dilakukan oleh tujuh orang partisipan dengan menggunakan daftar periksa WISE yang terdiri dari 58 butir elemen periksa. Kemudian dibuat rekapitulasi berisi elemen periksa yang terpilih oleh setidaknya satu orang partisipan (Tabel 2).

Tabel 2. Rekapitulasi Pengisian Daftar Periksa WISE

\begin{tabular}{|c|c|c|}
\hline No & Elemen yang diperiksa & $\begin{array}{c}\text { Partisipan yang } \\
\text { memilih "YA" }\end{array}$ \\
\hline 1 & $\begin{array}{l}\text { Memeriksa, membersihkan } \\
\text { dan memelihara mesin-mesin, } \\
\text { termasuk kabel listrik secara } \\
\text { teratur. }\end{array}$ & 7 orang \\
\hline 2 & $\begin{array}{l}\text { Memastikan } \\
\text { bahaya } \\
\text { kebakaran }\end{array}$ & 7 orang \\
\hline 3 & $\begin{array}{lr}\text { Menyediakan } & \text { perlengkapan } \\
\text { pelindung pribadi yang } \\
\text { memberikan } & \text { perlindungan } \\
\text { yang memadai. } & \end{array}$ & 7 orang \\
\hline 4 & $\begin{array}{l}\text { Membuat label untuk } \\
\text { menuliskan identitas produk }\end{array}$ & 7 orang \\
\hline 5 & $\begin{array}{l}\text { Menempatkan wadah limbah } \\
\text { yang terpisah di tempat kerja } \\
\text { untuk berbagai jenis limbah }\end{array}$ & 7 orang \\
\hline 6 & $\begin{array}{l}\text { Menyediakan sejumlah alat } \\
\text { pemadam kebakaran di dekat } \\
\text { area kerja. }\end{array}$ & 7 orang \\
\hline 7 & $\begin{array}{l}\text { Memastikan pekerja } \\
\text { mendapatkan pelatihan } \\
\text { memadamkan kebakaran. }\end{array}$ & 7 orang \\
\hline 8 & $\begin{array}{l}\text { Menggunakan kereta, troli, } \\
\text { atau perangkat lain yang } \\
\text { menggunakan roda ketika } \\
\text { memindahkan material. }\end{array}$ & 7 orang \\
\hline 9 & $\begin{array}{l}\text { Menetapkan kebijakan K3 dan } \\
\text { menyediakan pelatihan } \\
\text { keselamatan dan kesehatan } \\
\text { yang memadai bagi semua } \\
\text { pekerja. }\end{array}$ & 7 orang \\
\hline 10 & $\begin{array}{l}\text { Memastikan penyambungan } \\
\text { kabel menggunakan cara dan } \\
\text { alat yang aman }\end{array}$ & 6 orang \\
\hline 11 & $\begin{array}{l}\text { Menyediakan peralatan } \\
\text { pertolongan pertama (P3K) } \\
\text { dan melatih petugas P3K yang } \\
\text { memenuhi syarat. }\end{array}$ & 6 orang \\
\hline 12 & $\begin{array}{l}\text { Melindungi tempat kerja dari } \\
\text { panas luar yang berlebihan. }\end{array}$ & 5 orang \\
\hline 13 & $\begin{array}{l}\text { Menghemat ruangan dengan } \\
\text { menggunakan rak bertingkat } \\
\text { atau rak di dekat tempat kerja. }\end{array}$ & 5 orang \\
\hline
\end{tabular}

Tabel 2 tersebut menunjukkan 13 elemen periksa terpilih dari penilaian kondisi kerja menggunakan daftar periksa WISE. Ke-13 elemen memiliki persentase yang berbeda, sehingga diperlukan diskusi lebih lanjut untuk menentukan prioritas perbaikan mana yang akan diimplementasikan dalam waktu dekat dan waktu mendatang. 


\section{Pembuatan Rencana Aksi}

Rencana aksi merupakan daftar permasalahan beserta ide perbaikan yang dihasilkan melalui pelaksanaan FGD yang diikuti seluruh partisipan. Rekapitulasi hasil penilaian kondisi kerja masing-masing partisipan yang didapatkan dari tahap sebelumnya digunakan sebagai bahan diskusi untuk membuat rencana aksi ini, yaitu terdapat 13 elemen periksa yang terpilih untuk diusulkan sebuah perbaikan. Dengan mempertimbangkan faktor biaya, waktu dan sumber daya manusia, terdapat empat perbaikan yang dapat diimplementasikan dalam waktu dekat. Keempat perbaikan yang terpilih merupakan keputusan akhir diskusi FGD karena keempat perbaikan tersebutlah yang membutuhkan biaya murah, waktu perencanaan yang singkat dan implementasinya dapat memanfaatkan fasilitas yang ada.
Hal tersebut sesuai dengan prinsip dari pelaksanaan WISE dan PAOT, yaitu melakukan tindakan perbaikan dengan memanfaatkan sumber daya yang ada di UMKM.

Identifikasi empat perbaikan tersebut, menggunakan analisis $5 \mathrm{~W}+1 \mathrm{H}$. Model $5 \mathrm{~W} 1 \mathrm{H}$ memiliki karakteristik komprehensif yaitu mampu menampilkan suatu masalah dari berbagai sudut pandang/sisi, sehingga mampu mendeskripsikan akar suatu masalah dan tindakan yang efektif dan efisien sebagai solusinya. Rencana aksi yang telah dirancang, berisi 4 perbaikan yang akan diimplementasikan dalam waktu dekat, sedangkan 9 perbaikan yang lain tidak disajikan dalam tabel karena akan diimplementasikan dalam waktu mendatang dengan alasan memerlukan biaya serta waktu pelaksanaan yang membutuhkan perencanaan kompleks (Tabel 3)

Tabel 3. Rencana Aksi

\begin{tabular}{|c|c|c|}
\hline No & Elemen yang Terpilih & Identifikasi 5W1H \\
\hline 1 & $\begin{array}{l}\text { Memeriksa, membersihkan } \\
\text { dan memelihara mesin- } \\
\text { mesin, termasuk kabel } \\
\text { listrik secara teratur. }\end{array}$ & $\begin{array}{l}\text { Why: Karena tidak ada pembersihan dan pemeriksaan rutin, kabel-kabel } \\
\text { permesinan banyak yang mengelupas bahkan rusak akibat gigitan tikus. Kerugian } \\
\text { yang paling fatal ketika kabel rusak adalah mesin berhenti beroperasi, sehingga } \\
\text { menggangu jalannya produksi. } \\
\text { What: Perbaikan ini bersifat preventif yaitu pembuatan jadwal rutin untuk } \\
\text { pembersihan serta pemeriksaan mesin dan jaringan kabel listrik. Karena sejauh } \\
\text { ini percetakan hanya melakukan pemeriksaan dan perbaikan apabila memang } \\
\text { terjadi kerusakan } \\
\text { Where: Akan diterapkan di percetakan XYZ di seluruh area kerja khususnya area } \\
\text { pencetakan spanduk. } \\
\text { When: Jadwal akan segera diterapkan dalam waktu dekat karena tidak perlu } \\
\text { membuat anggaran biaya yang cukup besar, namun yang diperlukan adalah } \\
\text { diskusi di antara pemilik usaha dan seluruh pekerja terkait waktu yang tepat untuk } \\
\text { pelaksanaan agar semua pihak bisa berpartisipasi. } \\
\text { Who: Menjadi tanggung jawab pemilik usaha dan pekerja, karena pelaksanaan } \\
\text { pembersihan dan pemeriksaan rutin harus menjadi kesadaran bersama. } \\
\text { How: Pemilik usaha dan pekerja telah merencanakan untuk melakukan } \\
\text { pembersihan serta pemeriksaan pada mesin serta kabel-kabel yaitu hari Minggu } \\
\text { pada minggu ke-2 di setiap bulan. Pemilihan hari Minggu karena jam kerja pada } \\
\text { hari tersebut hanya sampai pukul } 17.00 \text { WIB. Untuk mempermudah pemeriksaan, } \\
\text { akan disusun panduan atau daftar periksa berdasarkan aspek } 5 \mathrm{R} \text {. }\end{array}$ \\
\hline 2 & $\begin{array}{l}\text { Memeriksa, membersihkan } \\
\text { dan memelihara mesin- } \\
\text { mesin, termasuk kabel } \\
\text { listrik secara teratur. }\end{array}$ & $\begin{array}{l}\text { Why: Karena percetakan menggunakan bahan baku yang mudah tersulut api } \\
\text { seperti plastik dan kertas. Sementara itu, beberapa pekerja dan konsumen sering } \\
\text { kali merokok dan kurang memperhatikan kondisi serta tempat pembuangan } \\
\text { puntung rokok. } \\
\text { What: Pembuatan dan pemasangan tanda-tanda peringatan pada tempat yang } \\
\text { memiliki resiko bahaya kebakaran tinggi seperti area bahan baku dan juga } \\
\text { jaringan listrik seperti kumpulan kabel. } \\
\text { Where: Tanda peringatan dapat ditempatkan di area bahan baku yang banyak } \\
\text { terdapat plastik dan kertas. } \\
\text { When: Pemasangan tanda peringatan bisa segera diterapkan karena percetakan } \\
\text { ini bisa mencetaknya sendiri. Konsep dari tanda bahaya akan disesuaikan dengan } \\
\text { pedoman yang ada. } \\
\text { Who: Pemilik usaha dan pekerja. } \\
\text { How: Tanda peringatan bahaya untuk mencegah kebakaran akan dibuat } \\
\text { desainnya oleh operator desain sesuai aturan yang ada. Selanjutnya desain } \\
\text { dicetak di mesin stiker, sehingga bisa ditempel di area-area yang direncanakan } \\
\text { yaitu area bahan baku serta area mesin-mesin dan jaringan listrik. Pemilik usaha } \\
\text { dan pekerja perlu saling memberi teguran apabila ada yang masih melanggar } \\
\text { aturan untuk tidak merokok di area-area terlarang. }\end{array}$ \\
\hline
\end{tabular}


Tabel 3. Rencana Aksi (Lanjutan)

\begin{tabular}{|c|c|c|}
\hline No & Elemen yang Terpilih & Identifikasi 5W1H \\
\hline 3 & $\begin{array}{l}\text { Memeriksa, membersihkan } \\
\text { dan memelihara mesin- } \\
\text { mesin, termasuk kabel listrik } \\
\text { secara teratur. }\end{array}$ & $\begin{array}{l}\text { Why: Karena tidak ada pembersihan dan pemeriksaan rutin, kabel-kabel } \\
\text { permesinan banyak yang mengelupas bahkan rusak akibat gigitan tikus. Kerugian } \\
\text { yang paling fatal ketika kabel rusak adalah mesin berhenti beroperasi, sehingga } \\
\text { mengganggu jalannya produksi. } \\
\text { What: Perbaikan ini bersifat preventif yaitu pembuatan jadwal rutin untuk } \\
\text { pembersihan serta pemeriksaan mesin dan jaringan kabel listrik. Karena sejauh ini } \\
\text { percetakan hanya melakukan pemeriksaan dan perbaikan apabila memang terjadi } \\
\text { kerusakan } \\
\text { Where: Akan diterapkan di percetakan XYZ di seluruh area kerja khususnya area } \\
\text { pencetakan spanduk. } \\
\text { When: Jadwal akan segera diterapkan dalam waktu dekat karena tidak perlu } \\
\text { membuat anggaran biaya yang cukup besar, namun yang diperlukan adalah } \\
\text { diskusi di antara pemilik usaha dan seluruh pekerja terkait waktu yang tepat untuk } \\
\text { pelaksanaan agar semua pihak bisa berpartisipasi. } \\
\text { Who: Menjadi tanggung jawab pemilik usaha dan pekerja, karena pelaksanaan } \\
\text { pembersihan dan pemeriksaan rutin harus menjadi kesadaran bersama. } \\
\text { How: Pemilik usaha dan pekerja telah merencanakan untuk melakukan } \\
\text { pembersihan serta pemeriksaan pada mesin serta kabel-kabel yaitu hari Minggu } \\
\text { pada minggu ke-2 di setiap bulan. Pemilihan hari Minggu karena jam kerja pada } \\
\text { hari tersebut hanya sampai pukul } 17.00 \text { WIB. Untuk mempermudah pemeriksaan, } \\
\text { akan disusun panduan atau daftar periksa berdasarkan aspek } 5 \mathrm{R} \text {. }\end{array}$ \\
\hline 4 & $\begin{array}{l}\text { Memeriksa, membersihkan } \\
\text { dan memelihara mesin- } \\
\text { mesin, termasuk kabel listrik } \\
\text { secara teratur. }\end{array}$ & $\begin{array}{l}\text { Why: Karena percetakan menggunakan bahan baku yang mudah tersulut api } \\
\text { seperti plastik dan kertas. Sementara itu, beberapa pekerja dan konsumen sering } \\
\text { kali merokok dan kurang memperhatikan kondisi serta tempat pembuangan } \\
\text { puntung rokok. } \\
\text { What: Pembuatan dan pemasangan tanda-tanda peringatan pada tempat yang } \\
\text { memiliki resiko bahaya kebakaran tinggi seperti area bahan baku dan juga jaringan } \\
\text { listrik seperti kumpulan kabel. } \\
\text { Where: Tanda peringatan dapat ditempatkan di area bahan baku yang banyak } \\
\text { terdapat plastik dan kertas. } \\
\text { When: Pemasangan tanda peringatan bisa segera diterapkan karena percetakan } \\
\text { ini bisa mencetaknya sendiri. Konsep dari tanda bahaya akan disesuaikan dengan } \\
\text { pedoman yang ada. } \\
\text { Who: Pemilik usaha dan pekerja. } \\
\text { How: Tanda peringatan bahaya untuk mencegah kebakaran akan dibuat } \\
\text { desainnya oleh operator desain sesuai aturan yang ada. Selanjutnya desain } \\
\text { dicetak di mesin stiker, sehingga bisa ditempel di area-area yang direncanakan } \\
\text { yaitu area bahan baku serta area mesin-mesin dan jaringan listrik. Pemilik usaha } \\
\text { dan pekerja perlu saling memberi teguran apabila ada yang masih melanggar } \\
\text { aturan untuk tidak merokok di area-area terlarang. }\end{array}$ \\
\hline
\end{tabular}

\section{Implementasi Usulan Perbaikan dalam Waktu Dekat}

Perbaikan yang diimplementasikan dalam waktu dekat merupakan perbaikan yang membutuhkan sumber daya serta biaya tidak begitu besar dan pemilik usaha merasa sanggup untuk membiayainya, sedangkan perbaikan yang membutuhkan biaya cukup besar, sumber daya lebih banyak dan perencanaan yang lebih kompleks akan diterapkan pada waktu mendatang karena memerlukan persiapan yang matang.

4 elemen periksa yang perbaikannya akan diimplementasikan dalam waktu dekat yaitu, pertama adalah memeriksa, membersihkan dan memelihara mesin-mesin, termasuk kabel listrik secara teratur, kedua adalah memastikan adanya tanda bahaya pencegahan kebakaran, ketiga adalah menyediakan perlengkapan pelindung pribadi yang memberikan perlindungan yang memadai, dan keempat adalah membuat label untuk menuliskan identitas produk.

Perbaikan pemeriksaan, pembersihan dan memelihara mesin-mesin, termasuk kabel listrik secara teratur dilakukan dengan membuat jadwal rutin untuk pembersihan serta pemeriksaan mesin serta jaringan kabel listrik. Kegiatan ini diberi nama " $X Y Z$ Clean" yang akan menjadi tanggung jawab pemilik usaha serta pekerja dan pelaksanaannya adalah di minggu ke-2 setiap bulan (Tabel 4). Untuk mempermudah pemeriksaan, dari program WISE ini disusun sebuah pedoman pelaksanaan $X Y Z$ Clean yang mengadopsi prinsip-prinsip dasar dari 5R (ringkas, rapi, resik, rawat, rajin). Konsep 5R digunakan untuk mempermudah penataan area kerja yang baik (good housekeeping) dengan tujuan menumbuhkan budaya dan lingkungan yang bersih, meningkatkan budaya kerja yang efektif dan efisien, menciptakan lingkungan yang nyaman dan aman, menghilangkan pemborosan dalam aktivitas kerja, 
Tabel 4. Panduan Pelaksanaan XYZ Clean

\begin{tabular}{|c|c|}
\hline No & Aspek 5R \\
\hline 1 & $\begin{array}{l}\text { Ringkas, merupakan kegiatan menyingkirkan barang-barang yang tidak diperlukan sehingga segala } \\
\text { barang yang ada di lokasi kerja hanya barang-barang yang benar-benar dibutuhkan dalam aktivitas } \\
\text { kerja. Ringkas memiliki } 6 \text { langkah yaitu: } \\
\text { a. Memeriksa masing-masing barang seperti alat kerja, mesin, kabel listrik di setiap area kerja } \\
\text { b. Memilah barang-barang yang digunakan dan tidak digunakan } \\
\text { c. Menempatkan barang/peralatan yang sering digunakan sedekat mungkin dengan area kerja } \\
\text { d. Menempatkan barang yang kemungkinan akan digunakan kembali pada waktu mendatang } \\
\text { e. Menempatkan barang yang tidak akan digunakan kembali ke tempat pembuangan sampah } \\
\text { f. Memberi label tanda terhadap peralatan rusak vana masih bisa diaunakan dan diperbaiki. }\end{array}$ \\
\hline 2 & $\begin{array}{l}\text { Rapi, merupakan kegiatan meletakkan sesuatu sesuai posisi yang ditetapkan sehingga siap } \\
\text { digunakan pada saat diperlukan atau sering diartikan sebagai standarisasi penempatan setiap } \\
\text { barang. Rapi memiliki } 4 \text { langkah pelaksanaan yaitu: } \\
\text { a. Menempatkan barang-barang serta dokumen yang masih dipergunakan di tempat// } \\
\text { kotak/rumah-rumahan yang telah disediakan } \\
\text { b. Memberi label/identifikasi untuk mempermudah penggunaan maupun pengembalian ke tempat } \\
\text { c. Memula } \\
\text { d. Memastikan kerapian instalasi listrik, AC dan WiFi }\end{array}$ \\
\hline 3 & $\begin{array}{l}\text { Resik, merupakan kegiatan membersihkan peralatan dan area kerja sehingga selalu terjaga dalam } \\
\text { kondisi yang baik. Resik memiliki } 4 \text { langkah yaitu: } \\
\text { a. Menyiapkan alat kebersihan dengan fungsi dan jumlah yang memadai } \\
\text { b. Memastikan kebersihan lantai, dinding, serta langit-langit di seluruh area kerja khususnya dari } \\
\text { c. Mebu } \\
\text { d. Memastikan kebersihan mesin/ alat kerja/ komputer dari debu dan tinta }\end{array}$ \\
\hline 4 & $\begin{array}{l}\text { Rawat, merupakan kegiatan menjaga lingkungan yang sudah rapi dan bersih menjadi suatu standar } \\
\text { kerja. Tahap ini adalah memastikan bahwa ke-3R sebelumnya telah diterapkan dengan baik. Untuk } \\
\text { selalu menanamkan budaya rawat, perlu dibuat poster } 5 \mathrm{R} \text { yang nantinya ditempel di dinding } \\
\text { percetakan. }\end{array}$ \\
\hline 5 & $\begin{array}{l}\text { Rajin, merupakan kegiatan memelihara kedisiplinan pribadi (sadar dan peduli) masing-masing } \\
\text { pekerja dalam menjalankan seluruh tahap 4R. Rajin memiliki } 2 \text { langkah yaitu: } \\
\text { a. Membiasakan kondisi tempat kerja selalu sesuai dengan standar yang telah ditetapkan } \\
\text { b. Pemilik usaha sebagai pimpinan melakukan evaluasi setiap saat di area-area kerja, dan } \\
\text { memberi teguran pada area yang kurang maksimal menerapkan 4R. }\end{array}$ \\
\hline
\end{tabular}

menumbuhkan kesadaran diri untuk bekerja bersama dan semangat kolaborasi. Penerapan 5R yang konsisten diharapkan menjadi suatu kebiasaan bukan paksaan sehingga ide-ide perbaikan akan muncul dengan sendirinya secara terus menerus (continuous improvement).

Membuat tanda bahaya pencegahan kebakaran sebagai pengendalian administratif pada hierarki pengendalian risiko atau bahaya. Tanda bahaya maupun peringatan ini diharapkan akan memperkecil kemungkinan terjadinya kebakaran yang dapat menimbulkan kerusakan peralatan, fasilitas bangunan serta mengurangi kerugian yang lebih besar. Merokok merupakan kebiasaan yang dilakukan pekerja maupun konsumen di lingkungan percetakan. Tanpa disadari, aktivitas ini memiliki potensi untuk menimbulkan kebakaran akibat puntung rokok yang dibuang sembarangan. Untuk mengantisipasi hal tersebut, maka perlu adanya sebuah tanda peringatan bahaya dari merokok di beberapa area yang mudah tersulut api seperti area bahan baku yang banyak menyimpan bahan plastik dan kertas (Gambar 4).
Untuk merancang tanda bahaya pencegahan kebakaran yang sesuai dengan kondisi percetakan $X Y Z$, akan dilakukan melalui 4 tahapan (Clarion Safety Systems, 2013):

1. Melakukan penilaian kondisi area kerja khususnya tentang keberadaan rambu, tanda, marka keselamatan yang sudah ada.

2. Melakukan pemilihan tanda yang tepat

3. Memilih lokasi, ukuran dan gaya yang tepat

4. Memilih bahan yang tepat

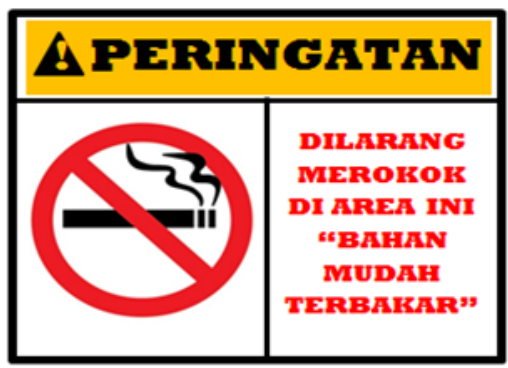

Gambar 4. Tanda Bahaya Pencegahan Kebakaran 
Pemilihan serta pemasangan tanda himbauan didasarkan pada pedoman OSHA/ANSI Z535. Tanda himbauan tersebut termasuk dalam kelompok "WARNING/PERINGATAN" yang akan dibuat menggunakan kertas stiker vinyl dengan ketinggian 115-167 cm diatas lantai (Gambar 4).

Penggunaan tinta solvent yang memiliki bau menyengat sering kali menyebabkan keluhan kesehatan dari para pekerja seperti kepala pusing dan perut mual. Pemilik usaha sebaiknya menyediakan masker dan sarung tangan sebagai alat pelindung diri untuk pekerja khususnya yang sering berinteraksi dengan penggunaan tinta solvent. Hal tersebut sesuai dengan pedoman yang termuat pada Peraturan Menteri Tenaga Kerja Dan Transmigrasi Republik Indonesia Nomor PER.08/MEN/VII/2010 Pasal 2 Ayat 1. Tetapi perbaikan akan menjadi lebih efektif, apabila dari pihak pekerja juga memiliki kesadaran untuk mempersiapkan alat pelindung diri secara mandiri.

Permasalahan lain yang timbul adalah rendahnya pengetahuan pekerja akan pentingnya pemakaian pelindung diri, walaupun disediakan pelindung diri tapi mereka mengabaikan untuk menggunakannya. Karena pemilik usaha tidak berada di percetakan sepanjang waktu untuk memberi teguran pada pekerja yang belum memakai pelindung diri, maka diperlukan sebuah tanda himbauan kesehatan yang mudah terlihat dengan tujuan menjadi pengingat tentang pemakaian pelindung diri di lingkungan kerja khususnya pekerja yang sering kontak langsung dengan tinta. Tahapan untuk merancang tanda berisi himbauan pemakaian pelindung diri terdiri dari 4 tahapan (Clarion Safety Systems, 2013). Tanda himbauan pemakaian pelindung diri yang telah dirancang dapat dilihat pada Gambar 5. Pemilihan serta pemasangan tanda himbauan didasarkan pada pedoman OSHA/ANSI Z535. Tanda himbauan tersebut termasuk dalam kelompok "NOTICE/PERHATIAN" yang akan dibuat menggunakan kertas stiker vinyl dengan ketinggian $115-167 \mathrm{~cm}$ diatas lantai.
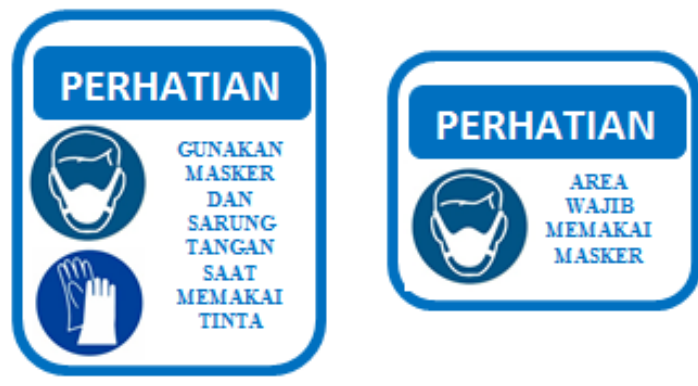

Gambar 5. Tanda Himbauan Pemakaian Pelindung Diri
Perbaikan label untuk menuliskan identitas produk dilakukan untuk mengurangi pemborosan waktu pada pekerja yang melakukan aktivitas mencari produk jadi spanduk yang akan diserahkan pada konsumen dari rak penyimpanan produk jadi. Label yang akan dibuat memuat setidaknya identitas nama konsumen dan judul konten spanduk sehingga memudahkan pekerja untuk mengenali produk yang akan diserahkan pada konsumen. Selain itu alasan penggunaan label adalah memberi informasi tentang isi produk tanpa harus membuka lipatan yang mengakibatkan penggunaan waktu lebih lama oleh pekerja.

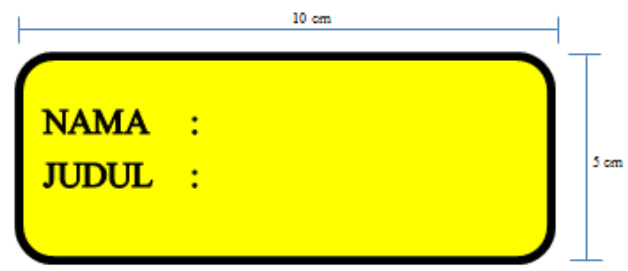

Gambar 6. Desain Usulan Label

Gambar 6 menunjukkan desain label yang akan dicetak menggunakan kertas stiker, kemudian penulisan identitas pada label akan dilakukan oleh admin bersamaan dengan pembuatan nota pembayaran dan kartu order. Proses penempelan label pada produk jadi akan dilakukan oleh operator finishing, bersamaan dengan aktivitas melipat spanduk. Alur produksi dalam pembuatan spanduk beserta usulan penambahan label identitas dapat dilihat pada Gambar 7.

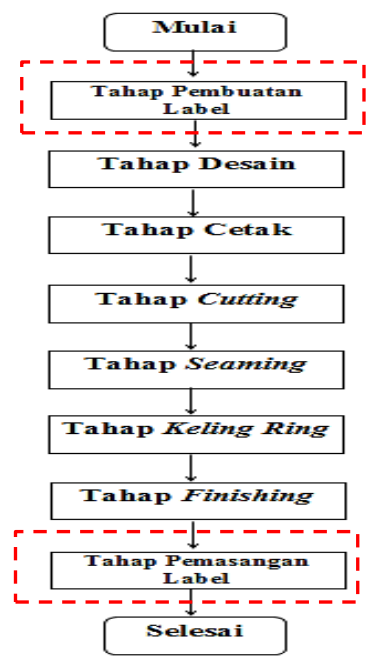

Gambar 7. Alur Produksi Spanduk Usulan

Empat perbaikan yang diimplementasikan dalam waktu dekat tersebut merupakan perbaikan dengan biaya yang murah karena hampir semuanya dapat diproduksi sendiri oleh percetakan seperti dalam pembuatan tanda/ rambu serta pembuatan label. Dalam penger- 
jaannya pun tidak membutuhkan proses dan waktu yang lama. Hal tersebut telah sesuai dengan tujuan WISE yaitu meningkatkan kondisi kerja dan produktivitas melalui perbaikan sederhana, efektif dan murah. Walaupun memiliki beberapa kelebihan, metode WISE juga memiliki kekurangan yaitu kemungkinan unsur subjektivitas yang tinggi. Untuk memperkecil kemungkinan tersebut, maka dalam pelaksanaannya perlu melibatkan berbagai pihak yang berperan sebagai sumber informasi untuk berdiskusi bersama memastikan persamaan persepsi dalam objek yang diteliti.

\section{KESIMPULAN}

Berdasarkan evaluasi kondisi kerja percetakan XYZ dengan pengisian daftar periksa WISE dengan pendekatan PAOT oleh seluruh partisipan, didapatkan hasil 13 elemen periksa yang terpilih untuk diberikan usulan perbaikan. Melalui pelaksanaan FGD dan analisis $5 \mathrm{~W} 1 \mathrm{H}$ untuk penyusunan rencana aksi, terdapat 4 elemen periksa yang perbaikannya akan diimplementasikan dalam waktu dekat setelah mempertimbangkan faktor biaya, waktu dan sumber daya manusia. Ide perbaikan pertama yang dilaksanakan dalam waktu dekat yaitu pembuatan jadwal rutin pembersihan serta pemeriksaan mesin, jaringan kabel listrik dan lingkungan kerja dengan pedoman 5R (ringkas, rapi, resik, rawat, rajin). Kedua adalah pembuatan tanda bahaya pencegahan kebakaran sesuai dengan standar ANSI Z535. Ketiga adalah pembuatan rambu atau tanda sebagai himbauan kesehatan untuk selalu memakai pelindung diri di lingkungan kerja untuk meminimalisir kontak langsung dan paparan dari tinta sesuai dengan standar ANSI Z535. Keempat adalah pembuatan label yang memuat identitas produk yang akan diserahkan pada konsumen. Penelitian selanjutnya dapat dilakukan dengan menerapkan WISE pada sektor UKM lainnya untuk membantu upaya yang dilakukan oleh pemerintah dalam meningkatkan kesadaran serta motivasi dari pekerja dan pengusaha untuk perbaikan lingkungan kerja yang sesuai dengan standar penerapan K3 sehingga angka kecelakaan kerja dapat berkurang.

\section{DAFTAR PUSTAKA}

Ashari, A., Naiem, M. F., \& Rahim, M. R. (2013). Gambaran Keluhan Gangguan Kesehatan Pada Operator Percetakan Kota Makassar Tahun 2013. https://core.ac.uk/download/pdf/25491375.p df

Clarion Safety Systems. (2013). New OSHA/ANSI Safety Sign Systems for Today's

\section{Workplaces.}

https://www.ishn.com/ext/resources/Resour ces/white-

papers/Clarion_ISHN_Whitepaper.pdf

Damarasri, D. R., Partiwi, S. G., \& Gunawan, J. (2013). Penerapan Good Manufacturing Practice dan Work Improvement in Small Enterprise Pada Usaha Kecil dan Menengah Untuk Pemenuhan Standar Kesehatan (Studi Kasus: UKM Tempe Tenggilis Mejoyo Surabaya). In Tugas Akhir. Fakultas Teknologi Industri. Institut Teknologi Sepuluh Nopember (ITS). http://digilib.its.ac.id/public/ITS-paper33645-2509100002-paperpdf.pdf

Darwis, A. M., Noviponiharwani, N., Latief, A. W. L., Ramadhani, M., \& Nirwana, A. (2020). Kejadian Kecelakaan Kerja di Industri Percetakan Kota Makassar. Jurnal Kesehatan Masyarakat Maritim, 3(2), 155163. http://journalold.unhas.ac.id/index.php/jkmmunhas/articl e/view/10430

Hughes, P., \& Ferrett, E. (2015). Introduction to Health and Safety at Work: for the NEBOSH National General Certificate in Occupational Health and Safety. Taylor \& Francis. https://books.google.co.id/books?id=futzCg AAQBAJ

International Labour Organization. (2004). Work Improvement in Small Enterprises (WISE): Package for Trainers. International Labour Organziation.

https://www.ilo.org/moscow/informationresources/publications/WCMS_346459/lang --en/index.htm

International Labour Organization. (2013). Keselamatan dan Kesehatan Kerja di Tempat Kerja, sarana untuk Produktivitas. Pedoman pelatihan untuk manajer dan pekerja. International Labour Office. https://www.ilo.org/jakarta/whatwedo/public ations/WCMS_237650/lang--en/index.htm

Kazutaka, K. (2012). Roles of Participatory Actionoriented Programs in Promoting Safety and Health at Work. Safety and Health at Work, 3(3),

155-165. https://doi.org/https://doi.org/10.5491/SHAW .2012.3.3.155

Kementerian Ketenagakerjaan Republik Indonesia. (2015). Daftar Periksa 'Pembinaan Peningkatan Keselamatan dan Kesehatan Kerja pada Usaha Kecil dan Menengah dengan Metoda Pelatihan Partisipasi Aktif.' Jakarta: Kementrian Ketenagakerjaan Republik Indonesia. http://www.idki.org/info/11-info/75-daftarperiksa-pembinaan-peningkatan-k3-ukm- 
dan-wiscon

Manuaba, A. (1990). Beban tugas untuk Prajurit dikaitkan dengan Norma Ergonomi di Indonesia. Proceedings Seminar Nasional Tentang Ergonomi Di Lingkungan ABRI.

Purwo, S. (2010). Karakteristik Bencana Gagal Teknologi di Indonesia. Jurnal Dialog Dan Penanggulangan Bencana, 1(1), 8-20. https://perpustakaan.bnpb.go.id/jurnal/index .php/JDPB/article/view/21

Rahma, R. A. A., \& Hasanudin, A. (2019). Assessment of the Implementation of Occupational Safety and Health at the Gamelan Industry Center Using Hazop and Wise Methods. IDENTIFIKASI: Jurnal IImiah Keselamatan, Kesehatan Kerja Dan Lindungan Lingkungan, 5(2), 152-167. https://jurnal.d4k3.uniba-

bpn.ac.id/index.php/identifikasi/article/view/ 98

Suhardi, B., Kadita, M., \& Laksono, P. W. (2018).
Perbaikan Proses Produksi dengan Standar Cara Produksi Pangan yang Baik (CPPB) dan Work Improvement in Small Enterprise (WISE) pada Industri Kerupuk Sala. Simetris: Jurnal Teknik Mesin, Elektro Dan Ilmu Komputer, 9(1), 579-586. https://doi.org/10.24176/simet.v9i1.2020

Suhardi, B., Putri, N. I., \& Astuti, R. D. (2019). Implementation of CPPB-IRT, WISE, and Halal Guarantee System on Bread Production. Jurnal Teknik Industri, 20(1), 22-33.

https://doi.org/10.22219/JTIUMM.Vol20.No1 .22-33

Suhardi, B., Wardani, S. V., \& Jauhari, W. A. (2019). Perbaikan Proses Produksi Ikm XYZ Berdasarkan Kriteria CPPB-IRT, WISE, dan SJH LPPOM MUI. J@ti Undip : Jurnal Teknik Industri, 14(2), 93=102. https://doi.org/10.14710/jati.14.2.93-102 